\title{
The Determinants of Commercial Banks Profitability in Zimbabwe (2009-2014)
}

\author{
Tough Chinoda ${ }^{1}$ \\ Banking and Finance, Women University in Africa, Zimbabwe
}

\begin{abstract}
The aim of the research is to identify the determinants of bank profitability. The researcher identified that internal factors are the major determinants of bank profitability. A sample of 5 commercial banks out of a population of 18 was used. The researcher recommended that macroeconomic policies are of great important. Inflation reduces credit expansion by contributing to higher net interest margins. Thus, policies aimed at controlling inflation should be given priority in fostering financial intermediation. Since the output cycle matters for bank profits, fiscal and monetary police that are designed to promote output stability and sustainable growth are good for financial intermediation. Also fees and commission should be monitored and managed so that a customer is not deceived.
\end{abstract}

Key words: Bank charges, commercial banks, determinants, interest rates, profitability

\section{Introduction And Background To Study}

In an ailing economy like Zimbabwe, banking industry plays a pivotal role. Banks create money in the economy by availing loans to different economic sectors, thus banks are in the epicenter of capital formation. Banks, according to Jeucken (1999), receive money and pass it on to productive and needy sectors through mobilizing people and economic agents who are reluctant to deposit their money to deposit through offering attractive deposit rates.

Zimbabwe banks have been accused of paying paltry interest on savings whilst levying exorbitant account maintenance fees; actions that are seen as working against the need to grow national savings through the banking sector, which is critical to maintaining liquidity in the economy. The reluctance by banks to pay real returns on savings, coupled with high administrative charges that eat into the savings, have been singled out as the two major drivers of depositors away from the formal banking sector, a situation that has prompted authorities to threaten banks with legislated interest rates and bank charges. (Zimbabwe independent 08/30/12)

Commercial banks, merchant banks and building societies earned close to US\$192m in interest on loan advances and leases and more than US\$118m from other charges. Each banking institution earned between US\$1 million and US\$16m in bank charges between January and June 30 2014. While the official interest rate charges are said to be between $15 \%$ and $25 \%$, sources revealed that some banks even charge between $25 \%$ to 40\%. (Zimbabwe independent August 20, 2012) The Reserve Bank, however, continues to receive complaints from the transacting public regarding the high service charges and lending rates being levied by banking institutions and low interest rates payable on savings and current accounts. (RBZ mid-term monetary policy 2012)

Commercial banks in Zimbabwe are ripping off their depositors by charging corrosively high interest rates ranging between $15 \%$ and $25 \%$, and imposing exorbitant bank charges which have seen them making massive profits in an ailing economy. The low deposit rates coupled with high bank charges are not conducive for attracting savings; on the other hand the relatively high lending rates discourage borrowing by the productive sectors thereby inhibiting the growth of the economy therefore the researcher is going to carry out a study about other determinants of commercial banks profitability besides interest rates and bank charges

\subsection{Research Objectives}

The main objective of this research is to come out with key drivers of commercial banks profitability in Zimbabwe, by evaluating internal and external factors which influence profitability of commercial banks. The sub-objectives of the researcher are to:

- identify the determinants of commercial banks profitability

- analyze the causes of high interest rates and excessive bank charges

- address the impacts of high interest rates and exorbitant bank charges to the economy, policy implication and suggest directions for further studies

\subsection{Reserch Hypothesis}

H1: Internal determinants are the major determinants of commercial banks profitability

H2: External determinants are the major determinants of commercial banks profitability 


\subsection{Theoratical Literature}

\section{Literature Review}

\subsubsection{Drivers of commercial bank profitability}

Determinants of commercial bank profitability can be split between those that are internal and those that are external. Internal determinants of bank profitability can be defined as those factors that are influenced by the bank's management decisions and policy objectives, Staikouras and Wood (2002). External determinants of commercial bank profitability are concerned with those factors which are not influenced by specific banks decisions and policies, but by events outside the influence of the bank. Several external determinants are included separately in the performance examination to isolate their influence from that of bank structure so the impact of the formers on profitability may be more clearly discerned, ElionaGremi (2013). Following are factors which influence bank profitability

The availability of loans is a factor that influences bank profitability. Commercial banks borrow money for the purpose of lending at a higher rate of interest. Bank grants various types of loans to the industrialists and traders thus most of the bank's income is generated from loan production. The margin between the interest rate the bank pays the depositors and interest rate it charges for loans represents the bank's profit. Therefore, the higher a bank's loan-to-deposit ratio, the more money it can earn in terms of lending revenue, K. Kinsella (2014). The banks grant loans generally for short periods.

Inflation has an indirect influence on commercial banks, it's impact lies on their customers and the subsequent changes in their demand for different kinds of financial services. Unexpected rises of inflation cause cash flow difficulties for borrowers which can lead to premature termination of loan arrangements and precipitate loan losses. Furthermore, inflation is one of the main routes through which it is possible to affect the operations and margins of banks through interest rates, Staikouras and Wood (2002). Inflation exacerbates so-called frictions in credit markets. In smoothly operating credit markets, banks can easily adjust nominal interest rates when they need to, but frictions create obstacles that make this adjustment difficult, Boyd and Champ (2006). The relationship between inflation and commercial bank profitability depends on the type of inflation (either the inflation is anticipated or unanticipated). If the inflation is anticipated in nature, the income of commercial banks will grow faster than costs of commercial banks since banks will be able to timely change interest rates. K.Rama\& T. Lakew (201

Capital adequacy plays a major role in determining bank profitability, to achieve an efficient intermediation process, and finally to provide desired levels of specific banks products or service higher capitalization foster the profitability because banks with higher capital ratio engage in prudent lending, they are able to lower their funding cost since large share of capital is a key indicator of creditworthiness. Also a well capitalized bank borrows less in order to support a given level of assets. (Molyneux, 1993).

The deposits of the public like demand deposits, savings deposits and fixed deposits constitute an important item on the liabilities side of the balance sheet. The success of any banking business depends to a large extent upon the degree of confidence it can instill in the minds of the depositors. The bank can never afford to forget the claims of the depositors. Hence, the bank should always have enough cash to honor the obligations of the depositors, Somashekar, (2009)

Interest rates also determine bank profitability. The funds raised by the bank through various sources are deployed in various assets. These assets yield income in the form of interest and the, higher the interest the greater the profitability. Another driver of income is spread which is the difference between the interest income and the interest expense. Higher spread indicates more efficient financial intermediate and higher net income. Thus, higher spread leads to higher profitability. ( Shah, 2010)

Market concentration also determines commercial bank profitability, which means that commercial banks in highly concentrated markets tend to collude and earn monopoly profits. Concentration may act as a barrier to entry when entering markets where domestic banks are highly concentrated, implying a negative impact on profits while market dominated by foreign banks that have been found to be more efficient than domestic banks, such as in less developed countries, concentration may in fact be positively related to foreign banks' profitability, Kosmidou et al (2007)

The desire to manage expenses also determines bank profitability. Operating costs are the expenses incurred in the functioning of the bank besides cost of funds. Lower operating costs give rise to greater profitability of the banks. Other costs are those associated to the probable annual loss on assets which include provisions made towards bad debts and doubtful debts. Lower risk costs increase the profitability of banks, (Shah,2010)

Asset quality is another factor that is considered by banks in determining profitability.There seems to be a consensus that bank profitability is directly related to the quality of the assets on its balance sheet; i.e. poor credit quality has a negative effect on bank profitability and vice versa. This relation exists because an increase in the doubtful assets, which do not accrue income, requires a bank to allocate a significant portion 
of its gross margin to provisions to cover expected credit losses; thus, profitability will be lower. TrujilloPonce et al, (2010).

A change in the technology and economic environment will stimulate financial institutions to search for financial innovations. Changes in demand conditions, especially the rise in interest-rate risk; changes in supply conditions, especially improvements in information technology; and the desire to avoid costly regulations have been major driving forces behind financial innovation. The resulting squeeze has hurt profitability in banks' traditional lines of business and has led to a decline in traditional banking. (Shah, 2010)

The availability of liquidity is another bank profitability determinant. This is the ability of the bank to obtain cash, in order to meet present and necessary needs. For the commercial banks to gain public assurance they should have sufficient liquidity to meet the demands of depositors and loan holder. Thus commercial banks should have effective assets and liabilities management system to reduce the noncompliance of assets and liabilities and to raise returning. Also, due to the inverse relationship between liquidity and profitability, building a perfect balance between these two variables is also vital (Ahmadzade et al., 2005).

\subsubsection{Factors Considered When Determining Interest Rates}

An interest rate is the amount received in relation to an amount loaned, generally expressed as a ratio of dollars received per hundred dollars lent. However, a distinction should be made between specific interest rates and interest rates in general. Specific interest rates on a particular financial instrument (for example, a mortgage or bank certificate of deposit) reflect the time for which the money is on loan, the risk that the money may not be repaid, and the current supply and demand in the marketplace for funds available for lending, L. Georgievska et al (2011).. Interest rates never remain same they keep on changing because they depend on many factors such as

Inflation affect interest rates since the rates paid on most loans are fixed in the loan contract. A lender may be reluctant to lend money for any period of time if the purchasing power of that money will be less when it's repaid; the lender will, therefore, demand a higher rate (known as an "inflationary premium"). Thus, inflation pushes interest rates higher; deflation causes rates to decline. Over time, as the cost of products and services increase, the value of money decreases. Consumer will therefore have to spend more money for the same products or services which had cost less in the previous year. Achin (2011)

Operational costs, such as staff costs, for most commercial banks are high and this has a bearing on the determination of base lending rates. In particular, staff loans had, on one occasion, been explicitly included in the calculation of the base lending rate. This, it can be inferred that these loan costs were being passed directly onto clients. The high staff costs may be due to the fact that new banks entering the market have to "poach" staff from existing banks, therefore resulting in higher salaries which become sticky downwards. Bank of Zambia (2010)

One of the government's strategies to control the flow of money within its consumers is through the monetary policy. The money supply has a major effect on both the level of economic activity and the inflation rate. If the central bank wants to stimulate the economy, it increases growth in the money supply. The initial effect is to cause interest rates to decline but a larger supply of money may lead to an increase in expected inflation which will push interest rate up. If the central bank eases credit, interest begins to decline but interest rate increases again if the central bank tightens credit. Solomon (2013)

Inflation affect interest rates since the rates paid on most loans are fixed in the loan contract. A lender may be reluctant to lend money for any period of time if the purchasing power of that money will be less when it's repaid; the lender will, therefore, demand a higher rate (known as an "inflationary premium"). Thus, inflation pushes interest rates higher; deflation causes rates to decline.Over time, as the cost of products and services increase, the value of money decreases. Consumer will therefore have to spend more money for the same products or services which had cost less in the previous year Achin (2011)

\subsection{Empirical Literature}

\subsubsection{Determinants Of Commercial Bank Profitability}

The profitability of a bank may be influenced by certain factors which are grouped into internal and external factors. Some of these factors may have a positive impact on the bank's profitability while the others could have a negative impact. Internal factors are those factors that the bank managers have control, they are also influenced by policies and decisions of a bank's management. Thus they basically reflect differences related to policies and decisions of a bank's management with regard to and uses of funds, capital, liquidity and expense management. therefore the impact of internal factors on bank profitability can be analyzed by looking at the balance sheet and income statement of the concerned commercial bank, K.Rama\&Tekeste (2012). Those factors over which the management of a bank lacks control are external to the 
bank. These factors generally relate to the industry and macroeconomic variables within which the bank operates.

Tobias Olweny (2011) revealed that a $1 \%$ increase in capital adequacy could result in $0.076 \%$ increase in profitability. This was statistically significant at $1 \%$ (5.464), which shows that well capitalized banks face lower cost of bankruptcy and lower need for external funding especially in emerging economies where external borrowing is difficult and costly. Uhomoibhi Toni Aburimet (2005) indicate that though capital size is a significant determinant of bank profitability in Nigeria, only the size of the reserves component of bank capital has a significant relationship with bank profitability. Thus the above theories reveals that well capitalized banks face lower costs of going bankrupt and then cost of funding is reduced, which is also a positive sign that the banks hold sufficient capital to hedge against risks, therefore enhances their financial stability

Loan is the major source of income and is expected to have a positive impact on bank performance. Other things constant, the more deposits are transformed into loans, the higher the interest margin and profits, SehrishGul (2011). The loan to deposit ratio have a positive relationship with profitability and more than $80 \%$ of the profit of commercial banks is from interest income, so management should maintain balance between the deposits, Dr. NadeemSohail et al (2013). It can be noted that the higher the ratio the lower the liquid the bank is. However, if a bank needs to increase risk to have a higher loan-to-asset ratio, then profits may decrease

MohanaRaoi\&BerhanuLakewe (2012), shows that expense management of the banks, measured by the ratio of cost to income, is statistically significant and is negatively correlated with profitability. The result of the study implies that more operationally efficient commercial banks reported higher profits than those commercial banks that have poor expense management over the study period affect the profitability of commercial. Dr. NadeemSohail et al (2013) considered expense efficiency as having negative impact on the profitability thus the managers should pay attentions on controlling the direct, operating and administration costs. Generally poor operational efficiency is one of the factors that negatively affect profitability since a reduction in cost increases profits.

European central bank (1999) stated that the information communication technology developments have had a strong influence on the structure and the activities of the banking sector. The elements that have changed are several, besides allowing transactions to be conducted more efficiently; technology allows banks to market their products more effectively. The technology deployed in banks affects its operational efficiency and determines its competitive position in the market (Brickwork ratings2008).

In Ghana inflation increased at the rate of about $23 \%$ on average annually during financial crisis period, banks in Ghana were forced to increase their base lending rate hence they experienced profitability during those recent years of the global financial crisis William Bentum (2012). Also worth mentioning is DevinagaRasiah (2010) who also reveals that annual rate of inflation have a significant positive impact on the profitability of the banks during these years of the crisis. Thus when inflation increases it exerts upwards pressure on interest rates which causes the banks to increase their base lending rates as stated above in order to offset the imbalances in their incomes and as a result experience profitability.

.Valentina Flamini et al (2009) revealed that market concentration has no direct effect on bank profitability in their estimation. However, they were aware of the limits of their measure of market concentration as a proxy for market power. Nevertheless, results show a positive, but insignificant effect of overhead costs on bank profitability. Since overhead costs are high in SSA, they would expect this variable to enter the regression significantly and with a negative sign.

\subsubsection{Causes Of High Interest Rates And Excessive Bank Charges}

The empirical findings show that the coefficient of the market share is always positive and statistically significant. Agreeing to the preferred specification, an increase in the market share by 1 percentage point will cause an increase in the lending rates by 0.3 percentage points, 19 ranging from 0.2 to 0.6 percentage points in the various specifications. These results suggest that a more concentrated domestic banking sector may cause a rise in the cost of credit. Georgievska et al (2011).

Delfiner and Peron (2007) indicates that high administrative costs are high as a result of the nature of the business, which involves charging high interest rates for making successful micro and small enterprise loans that are commercially sustainable. This is in line with Thiaman, (2013) who indicates that the major portion of a bank's profit comes from the fees that it charges for its services and the interest that it earns on its assets. Therefore it clearly shows that banks are passing on their costs to customers, however implementation of interest rate controls in some countries discourage banks from entering micro-finance

The other possible reason for the high profitability in commercial banking business is the existence of huge gap between the demand for bank service and the supply as a result there is less competition and banks charge high interest rates. This is evidenced in East Africa where the few government owned banks take the 
lion's share of the market, (Ongore 2013). Grenade (2007) also came with the same reason stating that competitive pressures resulting from conditions of free entry and competitive pricing will raise the efficiency of intermediation by decreasing the spreads between deposits and lending rates.

Kinsella (2014) reveals that properties in certain regions such as homes in coastal areas are more at risk of sustaining damage from floods and hurricanes. Some banks charge higher interest rates on secured loans if the collateral securing the loan is exposed to an above average risk of incurring damage. Takeover of one bank by another generally results in the public being assessed higher service charges for access to banking services, especially for access to checking account services, for conducting transactions through an ATM and for access to credit (Rose ,1997)

\subsubsection{Impacts Of High Interest Rates And Exorbitant Bank Charges To The Economy}

If the interest rate goes up the cost of borrowing to companies increases and this reduces their profitability. This is one reason why their share price tends to go down. An increase in interest rates also reduces the value of corporate bonds. The rate of interest the bonds pay is less attractive because interest rates have gone up. This also impacts on exports thus foreign institutional investors bring money into the country to get the benefit of the increased interest rate and convert their cash into sterling to deposit in banks. This drives up the price of the pound in the forex market. As a result exports to overseas markets become more expensive to buy as the local currency has devalued (Christopher, (2008)

Banks, apart from charging high interest rates on loans, also add all manner of administrative or miscellaneous charges which make the burden of borrowing unbearable. with the high interest rate, the mortality of small and medium enterprises (SMEs) becomes high as lack of cheap loans to grow their business interests will lead to high cost of production, low capacity utilization, staff rationalization (right-sizing and down-sizing), low sales as consumers may not be able to afford the goods and services, default in loan repayment, and ultimately, business collapse. (Kinsella, 2013)

Brownbridge (1998) reveals that by undertaking risky investment strategies (such as lending at high interest rates to high -risk borrowers) which, if unsuccessful, would jeopardize the solvency of the bank. Bank owners have incentives to undertake such strategies because, with limited liability, they bear only a portion of the downside risk but stand to gain, through higher profits, a large share of the upside risk. In contrast, the depositors gain little from the upside risk but bear most of the downside risk.

Also a risk to banks from higher rates is that more of their customers will struggle to repay their loans. Quantifying this risk is difficult since loan losses are influenced not just by interest rates but also by economic growth and employment, both of which would need to improve for central bankers to dial back their interventions. Even so, there are worrying signs. Higher rates could push many into default. The dilemma for policymakers is that keeping rates low for long is dangerous so is letting them rise too quickly. (Wilberman, 2012)

Olaleye (2009) indicates that higher interest rates increase income, for those with thigh levels of savings (income effect). Therefore, some consumers may actually increase spending thus an increase in interest rates is unlikely to discourage investment. In Nigeria, levels of debt are high and the savings ratio low, therefore, rising interest rates will be more likely to reduce investment. High interest rates help to tamp down inflationary pressures, but they also slow the pace of economic growth. For this reason, businesses in particular pay close attention to the Federal Reserve Board's manipulation of interest rates in an attempt to predict the future direction of the economy. Also higher interest rates cause hot money flows, because it is more attractive to save money.

\subsection{Research design}

\section{3 Research Methodology}

A Quantitative research design was used because it has been employed by NegussieAyele (2012) while studying determinant of private commercial banks profitability in Ethiopia. It also helps to analyse the relationship between the drivers of profitability and return on assets, testing and validating already constructed theories about how and why phenomena occur and it allows one to more credibly establish cause-and-effect relationships.

\subsection{Population}

A population of eighteen commercial banks in Zimbabwe is used in this study

\subsection{Sample and Sampling techniques}

A sample of five commercial banks was selected using randomly selection technique was used in this study and for the purpose e of this study non probability sampling is going to be used. Convenience sampling is 
useful since elements selected will be unrestricted and accessible to the researcher and is able to tests ideas about the area of research

\subsection{Research Instruments}

Financial annual reports of listed companies and the study of relevant literature such as journals, websites and text books were used to collect relevant, sufficient and appropriate data for this research and the 2012 annual reports were used for the purpose of this study. With the advancement of information technology, it was also necessary to gather wide range of information through the Internet. A number of websites mainly those for the banks were looked into for the study

\subsection{Data collection}

Secondary data was used, the data was collected by reviewing companies annual reports, reports by the Zimbabwe Stock Exchange and Securities Commission of Zimbabwe, textbooks and media publication. The Reserve Bank of Zimbabwe publications, various reports on Zimbabwean banks, Zimbabwe Institute of Bankers and various journals on related fields. Other secondary data were obtained from published printed sources like books, research articles, magazines and newspapers.Data on the capital bases, average interest rates as well as banking sector deposits and loans of the banks were obtained from Monetary Policy Statements, National Budget Statements and annual financial statements of banks. The demerits of using secondary data is that not all data available is usually relevant and the data is usually found in an unrefined state hence time consuming in terms of deducing the meaning (Singh, 2006).

\subsection{Data presentation and analysis}

The data was presented by the use of tables, graphs and pie charts; which aids the understanding and summarizing of the findings. In line with earlier researches on commercial bank profitability ratios was used as measures of commercial bank profitability since they are inflation invariant which means that they are not affected by changes in general price level because the numerator and the denominator in the period-t profitability ratios would be measured in monetary terms based on period-t price levels. DevinagaRasiah (2010) indicates that the use profitability ratios are not affected by changes in price levels. And it is believed to be the most appropriate way of measuring profitability as time series analysis is used

Below is the general linear regression model employed:

$\mathrm{Yjt}=\mathrm{C}+\alpha \mathrm{Xjt}+\beta \mathrm{Zt}+\varepsilon \mathrm{jt}$

Where

Yjt $=$ dependent variable of a commercial bank $\mathrm{j}$ in a particular year $\mathrm{t}$

$\mathrm{J}=$ an individual commercial bank

$\mathrm{C}=$ intercept

$\mathrm{X}=$ internal drivers of profitability

$\mathrm{Z}=$ external drivers

$\beta$ and $\alpha=$ are co-efficient

$\varepsilon j \mathrm{jt}=$ error term

\section{1}

\section{Data Presentation, Analysis And Interpretation}

\section{Relationship between ROA and expense to income}

Fig 4.1 below shows the relationship between operating expenses and ROA and it can be easily noted that as the percentage of expenses to income increases ROA tends to decrease for instance when the ratio of expense to income was 92 percent ROA falls from 2 to 1.5 . ROA increases to 6 when expenses falls to 45 percent. Therefore it shows that management were now able to manage their operating costs 
Fig 4.1 Relationship Between Roa And Expense To Income Ratio

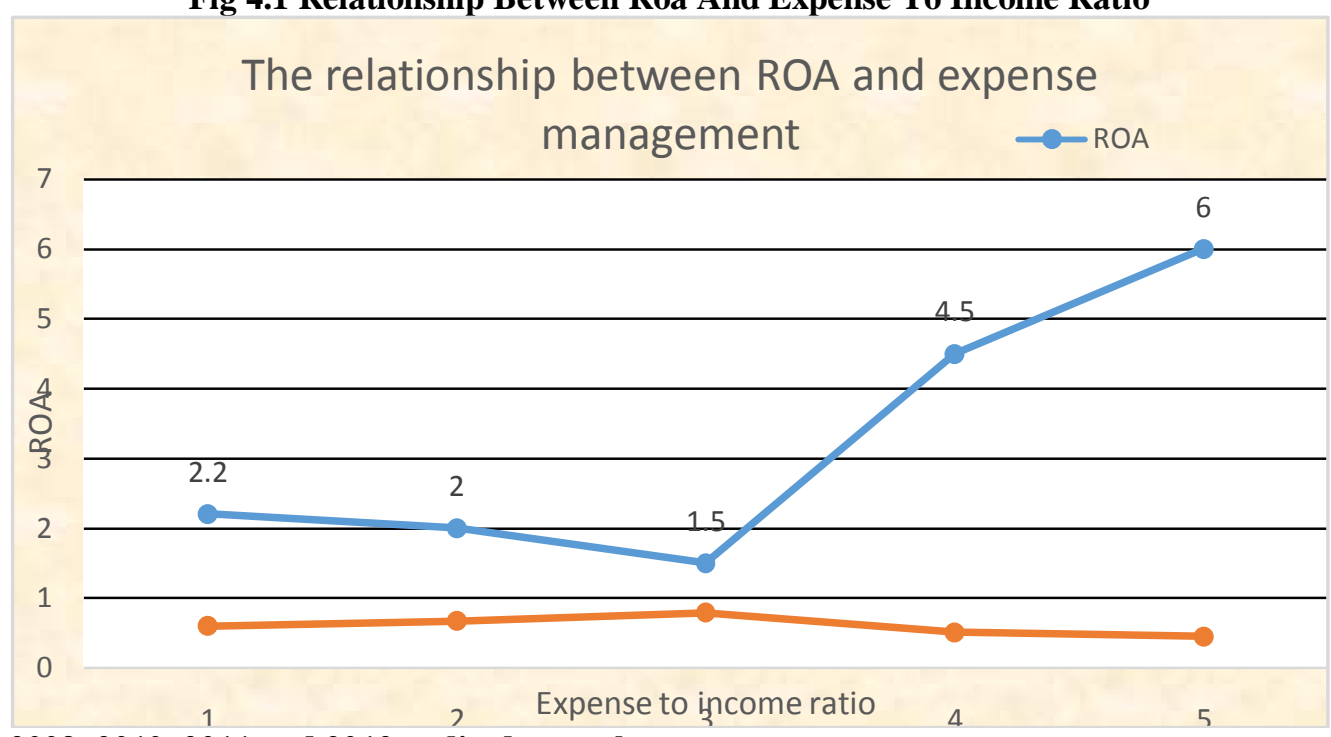

Source; 2009, 2010, 2011 and 2012 audited annual statements

\subsection{Total Annual deposits and loan to deposit ratios}

The loan-deposit ratio grew from 24\% in 2009, to 62.40 in 2010 to $78 \%$ in 2011 to $91 \%$ in 2012 as shown in Fig 4.3.1. As the value annual deposits increased the loan to deposit ratio also increased. This was also echoed by the Finance Minister, Mr. Biti during his 2013 National Budget presentation when he said that the loans and advances to the private sector marginally increased by $1.3 \%$ from US $\$ 3.10$ billion at the end of June 2012 to US $\$ 3,35$ billion as at 30 September 2012. By year end (31 December 2012) this had translated into a loan to deposit ratio of $91 \%$ reflecting increased exposures as some banks were exceeding liquidity threshold ratios of $30 \%$. This is a reflection of renewal confidence in the banking sector and improved economic activity since the introduction of the new minimum capital thresholds. Advances increased by nearly $\$ 250$ million during 2011 to 2012 which is a clear indication that recapitalization has had a positive impact on bank performance.

Fig 4.2: Total Annual Deposits And Loan To Deposit Ratio

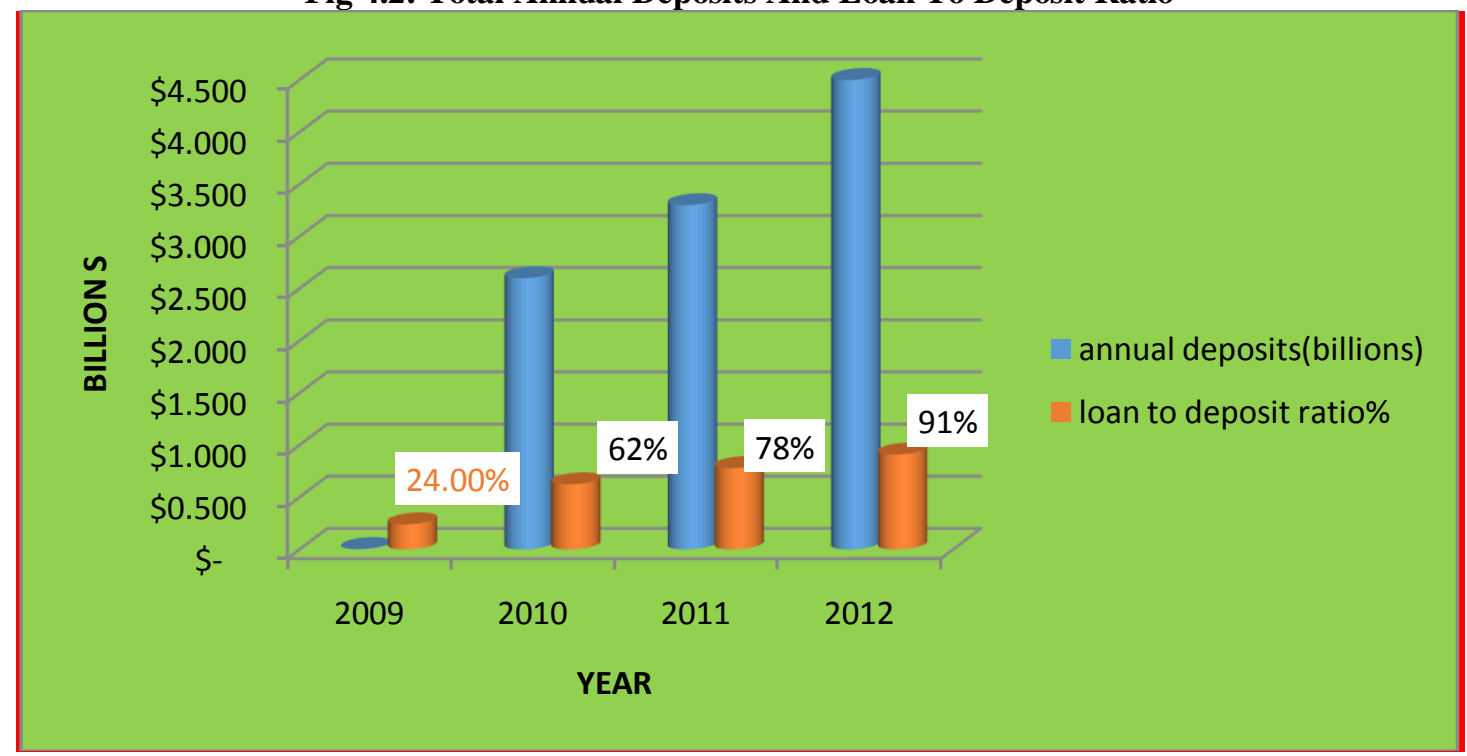

Source: Reserve bank of Zimbabwe

\subsection{Zimbabwean banking sector Interest rate trends}

The average interest rate for 2009 was $11,20 \%$ and it increased to $12.1 \%$, following that gradual increase in year 2010, it swiftly decreased in 2011 to $11.4 \%$, we can propound that the decrease was due to rapid increase in the minimum capital requirements however the capital adequacy rose again with a great margin to $13.35 \%$ as banks were now recovering from the capital threshold shock in 2012 and are now charging these high 
interest rates to customer making it difficult for other firms and individual to borrow so that they can revive their business thereby inhibiting

Fig 4.3: Zimbabwean Interest Rate Trend.

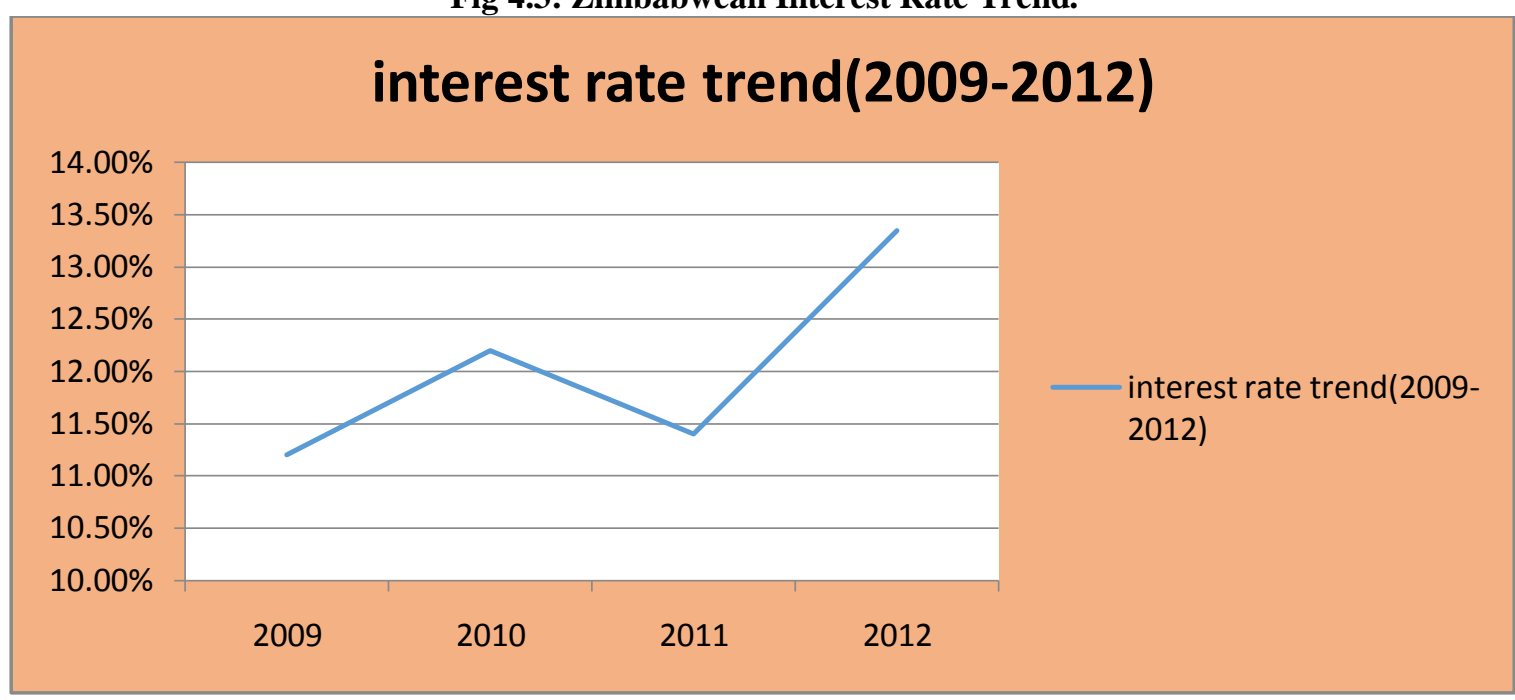

\section{Source: Zimbabwe stock exchange}

\subsection{Descriptive analysis}

TABLE 4.1 DESCRIPTIVE STATISTICS

\begin{tabular}{lllll}
\hline Dependent variables & Mean & Std. Dev & Min & Max \\
\hline ROA & & & & \\
ROE & 2.48 & 1.83 & -2.39 & 4.2 \\
\hline Internal independent variables & 19.32 & 7.31 & -18.45 & 46.2 \\
\hline Size & Mean & Std. Dev & Min & Max \\
Liquidity & 10.15 & 1.56 & 5.86 & 12.17 \\
Expenses management & 68.6 & 16.68 & 21.34 & 118.45 \\
\hline External independent variables & 0.58 & 1.98 & -0.04 & 0.46 \\
\hline Inflation & Mean & Std. Dev & Min & Max \\
GDP & 3.42 & 0.24 & -11.97 & 26.65 \\
\hline \hline
\end{tabular}

\section{Source ; computed from SPSS}

As it can be noted from the above table, return on asset has mean value of 2.48 , which is lowest as compared to return on equity. The standard deviation 1.83 and range 6.59 indicates that there was lowest variability in the data for the profitability measures. Return on equity has average value of 19.32 and which is the highest of all two dependent variables. The standard deviation 7.31 and range of 64.65 indicates high variability.

Table 4.1 also presents five explanatory variables which are expected to determine the profitability of commercial banks which are; expense management, liquidity, bank size, inflation and GDP and have different characteristics.

Expense management has the mean value of 0.58 , and the range of 2.02 which indicates the low variability, the standard deviation value of 0.46 which means that management are not efficiently managed

The mean value of liquidity of commercial banks was 68.6, and the range of 139.79 which is the highest variability among variables. The standard deviation value of the variable is 16.68 , which is the highest deviation as compare to other explanatory variables shows that the Zimbabwean commercial banks were very liquid by two times more than the minimum statutory liquidity ratio of 30 percent set by the Reserve Bank of Zimbabwe

Size of the bank plays an important role in maintaining the position of the bank in the market. The mean of commercial banks size obtained under this study was 10.15 , with the maximum and minimum values of 12.17 and 5.86 respectively. However the standard deviation value is 156 . These results indicates that commercial banks in Zimbabwe have a small variation in their total asset. 
The real GDP growth rate, has the standard deviation value of 0.33 , and the mean value of 3.48. The maximum and minimum value is 33.63 and -13.12 respectively. According to the above table, from the independent variables inflation and GDP growth rate have lowest standard deviation 0.24 and 0.33 compared with other variables. It revealed that the rate of inflation and level of GDP growth rate have little significant variance than other explanatory variables included in the study

\subsection{Regression results}

\subsubsection{Regression analysis between return on assets and explanatory variables}

To examine the relationship between profitability measures and explanatory variable two regression analysis were run on which the first was done to examine the relationship between ROA and the drivers of profitability

The following regression was applied

$\mathrm{ROA}=-5.49-0.07 \mathrm{EXP}+0.23 \mathrm{LQDTY}+1.62 \mathrm{SIZE}+1.33 \mathrm{INFL}+$
$0.75 \mathrm{GDP}$

In the following tablet $4.2 \mathrm{t}$-values, $\mathrm{p}$-values, coefficient and standard error for all predictor variables and the value of adjusted R-squared, S.E of regression, R-squared and also F-static, p-values and number of all observations incorporated in this study were presented.

$\mathrm{R}$-squared is a measure of the goodness of fit of the explanatory variables in determining the commercial banks profitability which means that the explanatory variables jointly explain about $81 \%$ using ROA of the variation in the profitability of commercial banks. The remaining 19 percent of the variation in the profitability of commercial banks can be explained by other variables which are not employed in the model. Beside this F-statistics (27.19) which is the used to measure the overall test of significance of the model was presented with a p-value of 0.04 which is below 0.05 shows the significant of the model

Table 4.2 Regression Result Between Roa And Explanatory Variables

\begin{tabular}{lllll}
\hline & coefficient & standard error & t-value & p-value \\
\hline C & -5.49 & 11.319 & -0.485 & 0.08 \\
expense management & -0.07 & 0.67 & -2.61 & 0.83 \\
Liquidity & 0.23 & 0.15 & 0.09 & 0.64 \\
Size & 1.62 & 0.22 & 1.23 & 0.01 \\
Inflation & 1.33 & 8.466 & 0.97 & 0.02 \\
GDP & 0.75 & 0.15 & 5.77 & 0.04 \\
\hline
\end{tabular}

\begin{tabular}{ll} 
R-squared & 0.81 \\
adjusted R squared & 0.72 \\
S.E of regression & 1.24 \\
Number of observations. & 5 \\
significant at 5\% & \\
F-static & 27.19 \\
Significant (p) & 0.04 \\
\hline
\end{tabular}

Source ; computed from SPSS

Expenses management was also found with a negative relationship with return on assets which makes this predictor a critical factor on influencing profitability. This results are consistence with the results of Tobias Olweny 2011 who revealed that $1 \%$ increase in operational costs could results in $0.068 \%$ decrease in profitability and Neceur (2003) come up with the same outcome for SSA and Tunisian banks respectively. Thus a lot of work needs to be done to minimize administrative costs and staff cost to improve the profitability of commercial banks in Zimbabwe. The negative impact of expense management shows that commercial banks are not able to pass on all their operating expenses to customers which may reflect a high level of competition or lack of market power in the banking industry.

Liquidity revealed a positive relationship with profitability which implies that investing in short-term less securities like government bonds will increase profitability. Nevertheless all coefficients were very weak which support the risky and return theory. The descriptive statistics analysis indicates that liquidity in the banking industry is far much above statutory limits which suggest that funds are being underutilized. This results was in line with those of Tobias Olweny (2011) and Ksmidou (2008). 
The positive and significant coefficient of the size variable support the economies of scale marketpower hypothesis. The positive coefficient indicates that larger commercial banks tend to earn higher profits than smaller commercial banks, and vice versa because they do not operate in very competitive market. This supports earlier reports of HoucemSmaoui (2010), Mohana Rao \&Lakew (2012). Hauner (2005) gives two potential explanations vis-à-vis the positive association between commercial bank size and commercial bank profitability. Initially, if this link relates to market power then large banks had to pay less for their inputs. There other reason is that there may be increasing returns to scale by the prioritization of the fixed costs over a higher volume of services or by efficiency advantages from a specialized workforce.

GDP find direct and significant impact on return on assets which indicates that rapid economic growth increase profitability of Zimbabwean commercial banks thus GDP captures improvements and downswings manifesting which happen in the business cycles. Consequently, movements in general activity level are expected to generate direct impacts on profitability of banks. In relation to the level of GDP the result is consistent with the findings of Belayneh (2011), Demirguc-Kunt and Huizinga (1999), Athanasoglou et al. (2008) and SehrishGul (2011). However the results tend to contradict with those of William Bentum (2012) who indicates that GDP has a negative relationship with commercial banks profitability and does conform to an aspect of priori assumptions.

The coefficient of inflation has a positive relationship with profitability which is consistent with previous studies of Athanasoglou et al, (2008) and Pasiouras et al, (2007) and also supports the hypothesis that high inflation rates are associated with high interest rates on loans, leading to higher bank profitability.

\subsubsection{Analysis of regression results between ROE and independent variables}

In order to know how much commercial banks in Zimbabwe are earning on their equity investment, return on equity (ROE) was employed in the regression analysis in relation with explanatory variables

Below is the regression model employed
$\mathrm{ROE}=-6.29-0.11 \mathrm{EXP}+$
$0.58 \mathrm{LQDTY}$
$+$
2.19SIZE
$-0.68$
INFL+
0.89GDP

The below table shows coefficient, standard error, $\mathrm{t}$-values, and $\mathrm{p}$-values for all explanatory variables and the value of R-squared, adjusted R-squared, S.E of regression. It also indicates F-statistics with pvalue and the total number of observations employed in the study

R-squared is a measure of the goodness of fit of the drivers of profitability in determining the commercial banks profitability. This means that the determinants jointly explain about $75 \%$ using ROA of the variation in the profitability of commercial banks as shown by table below. Therefore these variables collectively have a high explanatory power on the profitability of commercial banks in Zimbabwe. In other words about 75percent of the profitability of commercial banks can best be explained by these variables. To be precise, the F-ratio represents the ratio of improvement in the prediction that results from fitting the model, relative to the inaccuracy that still exists in the model. For this model the F-ratio is 11.23 which is very unlikely to have happened by chance and probability of this chance is less than $1 \%$. Since the calculated significance value is 0.03 and it is below 0.05 , therefore it shows that the regression model is statistically significant and fit for explaining why the commercial banks in Zimbabwe are making profit. There is a negative relationship between liquidity and bank profitability. Which means that the more liquidity the commercial bank, the lower the profitability. The result support the findings of Guru et) al (1999) who revealed a negative and relationship between the level of liquidity and profitability and also that of Haucem and Salah (2010)

The coefficient of inflation has a positive regression with profitability. These findings coincides with the findings are similar from Bentum (2012) and DevinagaRasiah (2010) which means that when inflation rises it exerts upwards pressure on lending rates which forces commercial banks to increase their base lending rates as stated above in order to offset the imbalances in their earnings and as a result experience profitability. Therefore the higher the rate of inflation, the higher the base lending rate which commercial banks borrow to their customers and high rate of inflation has always being one of the hindrance economic developments of Zimbabwe.

The empirical results shows that expense management has a negatively relationship with profitability. The findings of the study revealed that commercial banks which operate efficiently reports higher profits when comparing with those that has poor operating expense management over the study period. Thus, the empirical findings of the study indicate that a reduction in costs increases the profits of the commercial banks. Which implies that Zimbabwean commercial banks will profit more if management exercise efficient costs management practices this findings are inconsistence with those of Guru et al (1999) who indicates that efficiency in expense management increase profitability. 


\section{Conclusion And Recommendations}

5.1 Conclusion

The main objective of this study was to investigate the determinants of profitability of commercial banks in Zimbabwe. Balanced panel data from 2009 to 2012 of five commercial banks was analysed using multiple linear regression method. The data was analysed based on the financial statement of commercial banks in Zimbabwe and two regression models were used for two profitability measures which are ROA and ROE. The main results of the study findings from secondary data analysis are presented as follows

Analysis from descriptive statistics indicates that expensive management is not efficient because their operating expense per unit of operating return is high. The mean value of liquidity shows that commercial banks in Zimbabwe are very liquid by two more times than the minimum statutory liquidity ratio of 30 percent set by the Reserve Bank of Zimbabwe. Size of the bank has a mean value of 10.15 which indicates that commercial banks in Zimbabwe have a small variation in their total asset, from the independent variables inflation and GDP growth rate have lowest standard deviation 0.24 and 0.33 compared with other variables. It revealed that the rate of inflation and level of GDP growth rate have little significant variance than other explanatory variables included in the study

With regards to ROA liquidity, size, inflation, GDP growth rate has a positive relationship with profitability and are in agreement with both hypothesis though liquidity has a low coefficient which support the risky and return theory and it shows that it has a weak relationship with profitability. Expenses management was found with a negative relationship with return on assets which makes this predictor a critical factor on influencing profitability. The negative impact of expense management shows that commercial banks are not able to pass on all their operating expenses to customers who may reflect a high level of competition or lack of market power in the banking industry.

As for ROE liquidity and expense management have been found with a negative relationship with commercial bank profitability therefore rejecting Hypothesis 1 . Which means that the more liquidity the commercial bank, the lower the profitability and also a reduction in costs increases the profits of the commercial banks which implies that Zimbabwean commercial banks will profit more if management exercise efficient costs management practices. Size and inflation has a strong positive relationship with profitability, as for inflation it shows that when inflation rises it exerts upwards pressure on lending rates which forces commercial banks to increase their base lending rates as stated above in order to offset the imbalances in their earnings and as a result experience profitability and this support both Hypothesis 1 and 2. However GDP has a low positive relationship

\subsection{Recommendations}

Macroeconomic policies are of great important. Inflation reduces credit expansion by contributing to higher net interest margins. Thus, policies aimed at controlling inflation should be given priority in fostering financial intermediation. Since the output cycle matters for bank profits, fiscal and monetary police that are designed to promote output stability and sustainable growth are good for financial intermediation. Also fees and commission should be monitored and managed so that a customer is not deceived.

The improvement of the profitability of Zimbabwean commercial banks need to be conducted by a reinforcement of the capitalization of banks through national regulation programs, by reducing the proportion of non-interest bearing assets to the benefit of bank loans and by reducing the size of large banks to optimal levels while at the national level, we need to reduce concentration and spur.

Management of banks should identify the various forecasting techniques and applications and test them for suitability to their peculiar situations before implementing the techniques that turn out with the least forecasting error and also set up a competent researches; side by side with in-house machinery to ascertain study and monitor vital parameters influencing its earnings and give high priority to training and development so that commercial bank-planning staff can be acquainted with the latest developments and techniques that can improve their performance.

The management can control cost through different type of bargaining with the employees, marketing strategies such as unique service to the customers so that they attract cheap deposits and compliance with good corporate governance in the banking industry

\subsection{Future researches}

The study sought to investigate drivers of profitability of commercial banks in Zimbabwe. However the variables employed in the study were not exhaustive. Future studies should take into account other driver of profitability such as market concentration, asset quality and capital adequacy. Future researches should employ other methods of data analysis such as Data Envelopment Analysis and Economic Value Added for the purpose of protecting methodology bias and improving the interpretation of the performance of commercial banks more accurately. These methods should be tested to see if they arrive at the same result or not 


\section{References}

[1] Abreu, M., Mendes, V., 2002. Commercial Bank Interest Margins and Profitability: Evidence from E.U. Countries. Working Paper Series, Porto

[2] A Framework for Assessing Corporate Governance and Financial Risk, World Bank Publications, 2003 - 367 pages

[3] Ahmad ArefAlmazari 2014 Impact of Internal Factors on Bank Profitability: Comparative Study between Saudi Arabia and Jordan, Journal of Applied Finance \& Banking, vol. 4, no. 1

[4] Anna P. I. Vong and Hoi Si Chan (2009), Determinants of Bank Profitability in Macao: Macao Monetary Research Bulletin

[5] Barclays Bank of Zimbabwe Audited Financial Statements [online] Available: http://www.barclays.com

[6] Commercial Bank of Zimbabwe Audited Financial Statements [online] Available: http://www.cbz.co.zw

[7] Cooper, Donald R., and Pamela S. Schindler. Business Research Methods. 8th ed. New York: McGraw-Hill, 2004

[8] Demerguç-Kunt A. and H. Huizinga. 1999. "Determinants of commercial bank interest margins and profitability: Some international evidence", World Bank Economic Review, Vol.13: 379-408

[9] Dr Gideon Gono (2012) Mid-term Monetary Policy : RBZ

[10] Efficient Structure, Journal of Economics and Business, Vol. 58, pp.222-239.

[11] http://www.zimbabwesituation.com/news/zimsit_zims-economic-outlook-uncertain/

[12] http://www.theindependent.co.zw/2012/08/20/banks-ripping-off-depositors/ (1950hrs)

[13] http://www.theindependent.co.zw/2013/08/30/banks-should-stop-whingeing-be-creative/

[14] http://www.theindependent.co.zw/2012/08/24/banks-not-generating-super-profits/

[15] http://lexicon.ft.com/Term?term=commercial-bank

[16] http://www.economist.com/news/finance-and-economics/21580164-low-interest-rates-are-squeezing-banks-profits-higher-ones$\underline{\text { may-do }}$

[17] http://www.wisegeek.com/what-factors-affect-commercial-bank-lending-rates.htm

[18] Mona Abdulilah, Yousef Al-Ademi,( 2009), Profitability determinants of commercial banks in Panel Evidence from Malaysia International Journal of Commerce, Business and Management

[19] Munyambonera Ezra Francis (2013), Determinants of Commercial Bank Profitability in Sub-Saharan Africa, Canadian Centerof Science and Education

[20] Naceur, S. (2003). The Determinants Of The Tunisian banking Industry Profitability: Panel Evidence. ERF Research Fellow Department of Finance UniversitéLibre de Tunis.

[21] Performance of Commercial Banks in Kenya International Journal of Economics and Financial Issues Vol. 3, No. 1, 2013, pp.237252

[22] R. Jayaram, Namita R. Kotwani (2012), Industrial economics and telecommunications regulations-Technology \& Engineering - 304 pages

[23] Tobias Olweny (2011), effects of banking sectorial factors on the profitability of commercial banks in Kenya, Economics and Finance Review Vol. 1(5) pp. 